\title{
Improvement of growth performance, immunity and disease resistance in Nile tilapia, Oreochromis niloticus, by using dietary probiotics supplementation
}

\author{
Sameh Abdel azeem ${ }^{1 *}$, M. F. Dowidar ${ }^{2}$, Khater A. M. ${ }^{3}$ and Somayah M. M. Awad ${ }^{1}$ \\ ${ }^{1}$ Fish Health and Management Department, Central Laboratory for Aquaculture Research, Abassa, Abu Hammad, Sharkia, Egypt. \\ ${ }^{2}$ Faculty of Veterinary Medicine, Zagazig University, Egypt. \\ ${ }^{3}$ Department of Fish Physiology and Nutrition, Central Laboratory for Aquaculture Research, Abassa, Abu Hammad, Sharkia, Egypt.
}

Corresponding author. Email: samehabdelazeem7@gmail.com

Copyright (C 2018 Abdel azeem et al. This article remains permanently open access under the terms of the Creative Commons Attribution License 4.0, which permits unrestricted use, distribution, and reproduction in any medium, provided the original work is properly cited.

Received 18th November, 2017; Accepted 27th December, 2017

\begin{abstract}
This study evaluated the effect of probiotics on the growth performance, some immunological, biochemical and hematological parameters of Nile tilapia. Eight weeks feeding trials were conducted to examine the effect of three types of probiotics, multi-strain probiotics $\left(6 \times 10^{7} \mathrm{cfu} / \mathrm{g}\right)$, Bacillus subtilis $\left(1 \times 10^{11} \mathrm{cfu} / \mathrm{g}\right)$ and Saccharomyces cerevisiae $\left(2.6 \times 10^{10} \mathrm{cfu} / \mathrm{g}\right)$ in commercial names Protexin, Biogen-S and Diamond V respectively. Nile tilapia $(24 \pm 0.02 \mathrm{~g})$ was fed probiotic-incorporated diets as well as control diet (free of probiotics) in triplicates. At 4th and 8th week of feeding trial, the growth performance of fish fed different probiotics was higher than those fed the control diet. No significant difference was observed among fish fed different probiotics for 4 or 8 weeks. Blood profile showed an increase in hemoglobin $(\mathrm{Hb})$, red blood cell (RBCs), packed cell volume (PCV), total protein, and globulin while aspartate aminotransferase (AST), alanine aminotransferase (ALT) levels decreased in fish fed different types of probiotics. Probiotics supplementation improved fish innate immunity based on lysozyme and respiratory burst activities over the control diet evaluated at 4 th and 8th week. Likewise, significant up-regulation of the expression of cytokine genes, interleukin-1 (IL-1) and tumor necrosis factor alpha (TNF $\alpha$ ) estimated at 8th week by using quantitative RT-PCR were significantly higher than the control. After experimental period (8 weeks) fish from each group were challenged by pathogenic Aeromonas hydrophila $\left(4 \times 10^{8} \mathrm{cfu} / \mathrm{ml}\right)$ which exhibited better relative survival percentages than the controls. Dietary supplementation of probiotics improves growth performance, immune status and disease resistance in Nile tilapia. Also, the best results related to growth obtained from groups fed multi-strain probiotic.
\end{abstract}

Keywords: Aeromonas hydrophila, challenge, growth, immunity, Nile tilapia, RT-PCR Probiotics, proinflamatory cytokine, quantitative.

\section{INTRODUCTION}

Aquaculture is one of the fastest growing sectors of food production. Tilapia is a widespread freshwater cultured fish that can be reared under wide ranges of environmental conditions and can accept different protein sources in its diet (Welker and Lim, 2011). Outbreaks of viral, bacterial and fungal infections have caused significant economic losses in aquaculture worldwide. In addition, substantial broodstock mortality has been reported in farms due to poor environmental conditions, unbalanced nutrition, generation of toxins and genetic factors (Kautsky et al., 2000). In past decades, prevention and control of fish diseases were achieved by using chemical additives and veterinary drugs, especially antibiotics, even though such methods were later found to be responsible for generating significant risks to public health by promoting the selection, propagation and persistence of bacterial-resistant strains (FAO, 2016).

The interest of consumers for safe, pharmaceutical-free 
products, and the need of a sustainable aquaculture have encouraged the scientific research community to use probiotics as an ecofriendly health strategy to counteract aquaculture diseases (Balcázar et al. 2006, Wang et al. 2008b).

Probiotics are live microorganisms which confer health benefits on host when administered via the feed or to the rearing water. The beneficial effects of probiotics, such as improvement of food utilization, modulation of intestinal microflora, enhancement of immune responses and antagonism to pathogens, have been demonstrated (Balcázar et al., 2006; Irianto and Austin, 2002; KesarcodiWatson et al., 2008; Merrifield et al., 2010; Nayak, 2010; Wang et al., 2008b)

It has been shown that the modulation of immune response by probiotics comprised different responses in a variety of domestic animals and fish, including the induction of proinflammatory cytokines, the activation of natural killer cells, production of mucosal and systemic antibodies, increasing the phagocytic lysozyme and complement activities (Matsuzaki and Chin, 2000; Panigrahi et al., 2004; 2005).

Probiotic strains could inhibit the pathogenic bacteria by the production of inhibitory compounds as bacteriocins, siderophores, lysozymes, proteases, hydrogen peroxide, formation of ammonia and diacetyle (Verchuere et al. 2000), competition for essential nutrients and adhesion sites (Vine et al., 2004). In addition, the cell walls components of probiotic bacteria, such as $\beta$-glucan, lipopolysaccharide and peptidoglycans were attributed to the immunostimulatory effects in fish (Rengpipat et al., 2000; Gullian et al., 2004). Among the various benefits of probiotics, immunomodulatory activity is note-worthy in improving the overall health status of the fish. However, there is limited research available for immunomodulatory activity of probiotics, especially for the long-term use of probiotics in fish diets. Therefore, the current study was conducted to evaluate different commercial probiotics as feed supplements for Nile tilapia through estimation of their effects on growth performance, physiological, and immunological parameters. Also, fish challenge against pathogenic bacteria, Aeromonas hydrophila was evaluated.

\section{MATERIALS AND METHODS}

\section{Probiotics}

Probiotics with the trade name Protexin, Biogen-S, and Diamond V were used in the present study. Protexin, is a multi-strain probiotic, contains Lactobacillus plantarum, Lactobacillus rhamnosus, Bifidobacterium bifidum, Enterococcus faecium, Candida pintolepesii, Aspergillus oryzae in isolated forms (Not less than $6 \times 10^{7} \mathrm{cfu} / \mathrm{g}$ ) obtained from Australian Co., Ltd. Biogen-S contains Bacillus subtilis natto (Not less $1 \times 10^{11} \mathrm{cfu} / \mathrm{g}$ ) obtained from
The Samu median co., Ltd. Diamond V contains Saccharomyces cerevisiae $\left(2.6 \times 10^{10} \mathrm{cfu} / \mathrm{g}\right)$ obtained from Cedar Rapids, lowa, USA.

\section{Fish and experimental design}

Apparently healthy monosex Nile tilapia (Oreochromus niloticus) was collected from the nursery ponds of the Central Laboratory for Aquaculture Research, Abbassa, Abo-Hammad, Sharqia, Egypt, and kept in indoor fiberglass tank for two weeks for adaptation.

Fish $(24.01 \pm 0.02 \mathrm{~g})$ were distributed in 12 glass aquaria $(70 \times 60 \times 50 \mathrm{~cm})$ distributed as 20 fish per aquarium. Fish were divided into four groups in three replicates. The first group (T1) fed with control diet (basal diet) with no probiotic that was formulated as shown in Table 1. The proximate analysis of the basal diet indicated $39.9 \%$ crude protein, $10.89 \%$ crude lipid and $3.68 \%$ fiber according to the AOAC (2000). In the experimental diets, the 2nd group (T2) fed with (basal diet + Protexin). The 3rd group (T3) fed with (basal diet + Biogen) and the 4th group (T4) fed with (basal diet + Diamond), where they were added at a rate of $1 \mathrm{~g} / \mathrm{kg}$ diet. Probiotics were included to the basal diet through infusion then evenly coated with molasses according to method described by Noordiyana et al. (2015). The fish were tested diets fed three times daily at the rate $3 \%$ of live body weight for 8 weeks (Silva et al., 2015). The aquaria were supplied with dechlorinated tape water. The average of the temperature was $25^{\circ} \mathrm{C} \pm 1^{\circ} \mathrm{C}$ and the oxygen was adjusted for continuous aeration by using electrical air pumping compressors (RINA, Italy). Two-third of the aquarium water was changed daily. The fish per each aquarium were weighted weekly from the beginning of the feeding experiment and the diets amount was adjusted according to the increase in the total body weight.

\section{Growth performance and feed utilization parameters}

The average weight-gain (AWG), specific growth rate (SGR) and feed conversion ratio (FCR) was calculated accordingly through the following equations:

$W G \%(g / f i s h)=($ Average final weight $(g)-$ Average initial weight $(\mathrm{g})$ )/ Average initial weight $(\mathrm{g}) \times 100$. (Jauncey and Ross, 1982)

SGR $\%=100$ [In final body weight $(\mathrm{g})-$ In initial body weight (g)]/experimental period (day). (Siddiqui et al., 1988)

FCR $(\%)=$ Feed intake $(\mathrm{g}) /$ Body weight gain $(\mathrm{g}) \times 100$. (De Silva and Anderson, 1995)

\section{Hematological and biochemical parameters}

Three blood samples were collected from caudal vein 
Table 1. Ingredients and chemical composition of the basal diet.

\begin{tabular}{lc}
\hline Ingredients & Percentage of die \\
\hline Ground yellow corn Fish oil & 26.5 \\
Soya bean meal & 22 \\
Fish oil & 5 \\
Meat meal & 29 \\
Fish meal & 25 \\
Mineral and vitamin mixture (premix) & 1.5 \\
& \\
Calculated chemical analysis (\%) & \\
Crude protein & 39.9 \\
Crude lipid & 10.89 \\
Crude fiber & 3.68 \\
Ash & 9.11 \\
Moisture & 10.58 \\
\hline
\end{tabular}

according to Feldman et al. (2000) and were divided into three groups. The first sample group was taken at the 4th week of feeding experiment; the second group was taken at the 8th week while the third group was taken post experimental infection. Before sampling, fish were starved for $24 \mathrm{~h}$. Fifteen fish were used from each treatment (T1 to T4) to obtain blood samples (five fish per aquarium).

For heamatological analysis, the blood samples were collected with anticoagulant $10 \%$ ethylenediaminetetraacetate (EDTA) to measure hematocrit $(\mathrm{Ht})$, hemoglobin $(\mathrm{Hb})$, red blood cells (RBCs) and white blood cells (WBCs). Ht was determined as described by Dacie and Lewis (1991). (Hb) was determined by using cyanmethemoglobin colorimetric method after centrifugation at $540 \mathrm{~nm}$ according to Stoskopf (1993). The Total leukocytic count (WBCs) and erythrocytic count (RBCs) was carried out by using hemocytometer and special diluting fluid (Natt-Herrick) as indicated by (Martins et al., 2004). Differential leukocytic count was performed according to Feldman et al. (2000).

For biochemical analysis, the blood samples were allowed to clot overnight at $4^{\circ} \mathrm{C}$ and then centrifuged at $3000 \mathrm{rpm}$ for $10 \mathrm{~min}$. The non-hemolyzed serum was collected and stored at $-20^{\circ} \mathrm{C}$ until use. Aspartate aminotransferase (AST) and Alanine aminotransferase (ALT) activities were determined calorimetrically according to the method described by Reitman and Frankel (1957). Total protein (TP), albumin and globulin were levels assayed by the method of Grant et al. (1987), Doumas et al. (1981) and Doumas and Biggs (1972) respectively. The serum glucose was determined according to (Trinder, 1969).

\section{Respiratory burst}

Blood sample of $0.1 \mathrm{ml}$ was placed into micro titer plate and equal amount of $0.2 \%$ nitro blue tetra-zolium (NBT) solution was added and incubated for 30 minutes at room temperature. $0.1 \mathrm{ml}$ of NBT blood cell suspension was taken and added to a glass tube containing $1 \mathrm{ml} \mathrm{N}, \mathrm{N}$ dimethyl formamide and centrifuged for $5 \mathrm{~min}$ at $3000 \mathrm{rpm}$. The respiratory burst activity was read in spectrophotometer at $620 \mathrm{~nm}$ in $1 \mathrm{ml}$ cuvettes (Siwicki et al., 1985).

\section{Lysozyme activity}

The lysozyme activity was measured by using turbidity measurement according to Schäperclaus et al. (1992). A series of dilution was prepared by diluting the standard lysozyme from hen egg-white (Fluka, Switzerland) and mixed with Micrococcus lysodeikticus (ATCC NO. 1698 Sigma) suspension for establishing the calibration curve. Ten $\mu$ l of standard solution or serum were added to $200 \mu \mathrm{l}$ of Micrococcus suspension (35 mg of Micrococcus dry powder/95 ml of $1 / 15 \mathrm{M}$ phosphate buffer $+0.5 \mathrm{ml}$ of $\mathrm{NaCl}$ solution). The changes in the extinction were measured at $546 \mathrm{~nm}$ by measuring the extinction immediately after adding the solution which contained the lysozyme (start of the reaction) and after 20 min incubation of the preparation under investigation at $40^{\circ} \mathrm{C}$ (end of the reaction). The lysozyme content was determined based on the calibration curve and the extinction measured.

\section{Molecular analysis: RNA extraction and gene expression by quantitative RT (reverse transcriptase)- PCR}

Total RNA was extracted from the head kidney tissue at the end of the feeding period using RNeasy Mini kit (Qiagen, Germany) according to the manufacturer's 
Table 2. Primers used for the examination of the expressions of cytokine genes in the head kidney tissues of Oreochromis niloticus.

\begin{tabular}{|c|c|c|c|}
\hline Gene & Primer sequence & Product size & $\mathrm{Ta}$ \\
\hline$\beta$ Actin & $\begin{array}{l}\text { F. TGGGGCAGTATGGCTTGTATG. } \\
\text { R. CTCTGGCACCCTAATCACCTCT. }\end{array}$ & $165 \mathrm{bp}$ & $60^{\circ} \mathrm{C}$ \\
\hline TNF- $\alpha$ & $\begin{array}{l}\text { F. GCTGGAGGCCAATAAAATCA. } \\
\text { R. CCTTCGTCAGTCTCCAGCTC. }\end{array}$ & $339 \mathrm{bp}$ & $60^{\circ} \mathrm{C}$ \\
\hline IL1 $\beta$ & $\begin{array}{l}\text { F. TGCTGAGCACAGAATTCCAG. } \\
\text { R. GCTGTGGAGAAGAACCAAGC. }\end{array}$ & $371 \mathrm{bp}$ & $60^{\circ} \mathrm{C}$ \\
\hline
\end{tabular}

protocol. The quality and RNA concentration were assessed spectrophotometry by nanodrop spectrophotometer at $A_{260}$ and $A_{280}$ according to Wilfinger et al. (1997). Approximately $1 \mathrm{mg}$ of total RNA from each of the tissue samples was reverse transcribed to produce cDNA using a Quantitect® Reverse Transcription kit (Qiagen, Germany) where the manufacturer's instructions have been followed. Initially, PCR was performed using primers for $\beta$-actin, which served as reference (ref) gene for both the test sample and the control (calibrator) sample (Table 2). The expressions of interleukin-1 (IL-1 $\beta$ ) and tumor necrosis factor alpha (TNF- $\alpha$ ) were examined using the primers presented in Table 2 (Selim and Reda 2015). The PCR conditions were as follows: $94^{\circ} \mathrm{C}$ for 5 minutes, 40 cycles of $94^{\circ} \mathrm{C}, 55^{\circ} \mathrm{C}$ and $72^{\circ} \mathrm{C}$ for 10,30 and 40 seconds respectively, and extension at $72^{\circ} \mathrm{C}$ for 7 minutes. Generate a melt curve using the Applied Biosystem realtime PCR system software. The obtained data were analyzed according to the method described by Livak and Schmittgen (2001) which is also known as the $2^{-\Delta \Delta C T}$ method.

\section{Challenge test}

At the end of 8th week, pathogenic A. hydrophila $(0.5 \mathrm{ml}$ of $10^{8}$ bacterial cells $\mathrm{ml}^{-1}$ ) was injected $\mathrm{I} / \mathrm{P}$ to 21 fish/treatment (Aly et al., 2008). Inoculated fish were observed daily for 14 days and their mortalities were recorded. The relative level of protection (RLP) among the challenged fish was determined according to Ruangroupan et al. (1986).

RLP $\%=100$ - (treatment mortality \%/control mortality \%) $\times 100$

\section{Determination of antibody titer}

$0.2 \mathrm{ml}$ of serum was mixed with $2.4 \mathrm{ml}$ of physiological saline in an agglutination tube and a dilution series was established. $1 \mathrm{ml}$ of antigen suspension having $4.8 \times 10^{9}$ A. hydrophila per $\mathrm{ml}$ was added to each dilution stage to result in dilution sequences 1:25, 1:50, 1:100 and so on. The agglutination samples were allowed to stay at room temperature. The first reading was recorded after 30 minutes and the second after 3 to 6 hours. The result was checked again after 24 hours. The agglutination titer was the least dilution stage at which a positive agglutination occurred (Schäperclaus et al. 1992).

\section{Statistical analysis}

The data were subjected to homogeneity test. Statistical analysis was performed using the one way and two-way ANOVA according to Tamhane and Dunlop (2000), to test the effect of probiotics treatment and the duration of feeding. Duncan test was used as a post-hoc test. Data were considered significantly different when $P<0.05$. It was performed with SPSS statistical software version 11.0.

\section{RESULT}

\section{Growth performance}

Fish fed probiotics-enriched diets showed higher growth than those fed the control diet (Table 3). There was no significant difference $(p>0.05)$ in growth performance among fish fed different probiotics. The experimental groups (T2, T3 and T4) were significantly different $(p<0.05)$ in both average final weights and weight gains from the control (T1). The highest averages of final weight and weight gain were observed in the T2. Specific growth rate was not different $(p>0.05)$ between the experimental groups T2, T3 and T4, but the differences between each of these groups versus the control were statistically significant $(p<0.05)$. The T2 showed the highest SGR, which was significant $(p<0.05)$ in comparison with the control and also to the dietary- supplemented groups. The treated groups also showed significant difference $(P<0.05)$ in reduction in feed conversion ratio (FCR) compared to the control.

\section{Hematological and biochemical parameters}

All probiotics-supplemented groups were different from the control $(P<0.05)$ in hemoglobin density, numbers of RBCs 
Table 3. Effect of probiotics on growth performance of Nile tilapia, O. niloticus fed different probiotics for the first and the second month.

\begin{tabular}{|c|c|c|c|c|c|c|c|c|c|c|}
\hline \multirow{3}{*}{$\begin{array}{l}\text { Parameters } \\
\text { Treatment }\end{array}$} & \multicolumn{10}{|c|}{ Duration of treatments } \\
\hline & \multicolumn{5}{|c|}{ First Month } & \multicolumn{5}{|c|}{ Second Month } \\
\hline & $\begin{array}{c}\text { Initial body } \\
\text { weight (g) }\end{array}$ & $\begin{array}{l}\text { Final body } \\
\text { weight }(\mathrm{g})\end{array}$ & $\begin{array}{c}\text { Body gain } \\
\%\end{array}$ & $\begin{array}{l}\text { SGR }^{*} \\
(\% g / d)\end{array}$ & $\mathrm{FCR}^{\star \star}$ & $\begin{array}{c}\text { Initial body } \\
\text { weight (g) }\end{array}$ & $\begin{array}{l}\text { Final body } \\
\text { weight (g) }\end{array}$ & Body gain \% & $\begin{array}{c}\text { SGR } \\
(\% g / d)\end{array}$ & FCR \\
\hline T1 (Control) & $24.01 \pm 0.02$ & $32.99 \pm 0.28^{b}$ & $37.42 \pm 1.10^{b}$ & $1.06 \pm 0.03^{b}$ & $2.51 \pm 0.07^{b}$ & $24.01 \pm 0.02$ & $40.01 \pm 1.52^{b}$ & $66.64 \pm 6.19^{b}$ & $0.85 \pm 0.06^{b}$ & $3.07 \pm 0.28^{b}$ \\
\hline T2 (Protexin) & $24.03 \pm 0.02$ & $35.44 \pm 0.17^{a}$ & $47.49 \pm 0.62^{\mathrm{a}}$ & $1.30 \pm 0.01^{\mathrm{a}}$ & $2.04 \pm 0.02^{\mathrm{a}}$ & $24.03 \pm 0.02$ & $49.29 \pm 0.75^{a}$ & $105.09 \pm 3.04^{a}$ & $1.20 \pm 0.02^{\mathrm{a}}$ & $2.07 \pm 0.05^{\mathrm{a}}$ \\
\hline T3 (Biogen-S) & $24.04 \pm 0.01$ & $35.38 \pm 0.53^{a}$ & $47.13 \pm 2.2^{\mathrm{a}}$ & $1.29 \pm 0.05^{\mathrm{a}}$ & $2.06 \pm 0.08^{a}$ & $24.04 \pm 0.01$ & $47.45 \pm 2.49^{a}$ & $97.35 \pm 10.3^{\mathrm{a}}$ & $1.13 \pm 0.09^{a}$ & $2.25 \pm 0.19^{a}$ \\
\hline T4 (Diamond-V) & $24.01 \pm 0.01$ & $34.52 \pm 0.09$ a & $43.77 \pm 0.39^{a}$ & $1.21 \pm 0.01^{\mathrm{a}}$ & $2.19 \pm 0.02^{\mathrm{a}}$ & $24.01 \pm 0.01$ & $47.48 \pm 1.88^{a}$ & $97.73 \pm 7.79^{a}$ & $1.13 \pm 0.06^{a}$ & $2.18 \pm 0.16^{a}$ \\
\hline \multirow[t]{2}{*}{ One way ANOVA } & \multicolumn{10}{|c|}{$P$ Value } \\
\hline & 0.491 & 0.002 & 0.002 & 0.002 & 0.001 & 0.491 & 0.025 & 0.025 & 0.018 & 0.019 \\
\hline
\end{tabular}

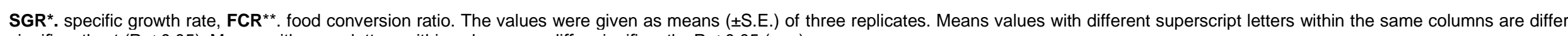
significantly at $(P \leq 0.05)$. Means with same letters within column non-differ significantly, $P \leq 0.05(a-c)$.

and hematocrit values within the two tested times of the study (Table 4). The highest hemoglobin density and hematocrit values were observed in T2 (Protexin supplemented group) at the 8th week. Otherwise, there was no significant difference $(p>0.05)$ in RBCs count among fish fed different probiotics. Neither duration of feeding nor its interaction with probiotics were of significant importance for all erythrogram parameters $(p$ $>0.05$ ), except for $\mathrm{Hb}$ density where it was significantly affected by feeding period. There was no significant difference $(p>0.05)$ in Mean Corpuscular hemoglobin concentration $(\mathrm{MCHC})$ of treated fish compared to the control.

The results of leukocytes examination (Table 5) showed significant rise $(p<0.05)$ in total leukocytic count as well as lymphocyte and monocyte percent in all groups compared to the control. Among the experimental groups, the T2 represented the highest count of lymphocytes and monocyte in comparison with the control at the 8th week. However, the percentages of neutrophils showed a marked decrease $(p<0.05)$ in the experimental fingerlings compared to the control within the 4th and 8th week. On the contrary to erythrogram results, feeding period of probiotcs was of significant importance $(p<0.05)$.

Table 6 showed a significant decrease $(p<0.05)$ in the serum levels of ALT, AST and glucose along the experimental periods were noticed in probiotics-supplemented groups in comparison with control (T1). Neither duration of probiotic feeding nor its interaction with probiotics had a significant effect on studied fish for transaminases. On the other hand, there was a significant $(p<0.05)$ increase in globulin and total protein of treated groups than the control ones.

\section{Immune parameters}

After the 4th week and the 8th week, NBT assay and lysozyme activity showed significant increase in T2, T3 and T4 in comparison with T1 Table 7. After the 4th and the 8th week, NBT assay showed significant increase in T2 than the values of T3 and
T4. The highest value of NBT assay obtained at T2 $(2.11 \pm 0.13)$ after the 4 th week and the lowest value obtained at T4 (1.6 \pm 0.09$)$ after the 4th week in comparison with $\mathrm{T} 1$. No statistic difference ( $p>0.05$ ) was noticed between the 1st and 2 nd month of the experiment in all treatments. On the contrary, lysozyme activity (Table 7) showed significant increase $(p<0.05)$ all over the experiment period in T2, T3 and T4 compared to control group. The highest value of lysozyme obtained at T3 $(1.87 \pm 0.12)$ after the 8th week in comparison with T1 (control) and the lowest value of lysozyme obtained at T4 $(1.29 \pm 0.06)$ after the 4th week. Statistics showed that duration of feeding was of significant importance for lysozyme activity but not for NBT.

\section{Gene expression of some proinflamatory cytokine (IL-1 $\beta$ and TNF- $\alpha$ ) in response to probiotics}

Fold changes in quantitative real time PCR for 
Table 4. Effect of probiotics on erythrogram of Nile tilapia fed different probiotics for the first and the second month.

\begin{tabular}{|c|c|c|c|c|c|c|c|}
\hline Groups & Month & $\mathrm{Hb}(\mathrm{g} \%)$ & RBCs $(106 / \mu \mathrm{l})$ & HCT (\%) & MCV (fl) & $\mathrm{MCH}(\mathrm{pg})$ & MCHC (\%) \\
\hline \multirow{2}{*}{ T1 (control) } & 1 & $3.05 \pm 0.09^{c}$ & $1.07 \pm 0.02^{b}$ & $12.60 \pm 0.26^{d}$ & $117.97 \pm 0.84^{\mathrm{a}}$ & $28.33 \pm 0.65^{a}$ & $24.03 \pm 0.7^{\mathrm{ab}}$ \\
\hline & 2 & $3.11 \pm 0.05^{c}$ & $1.15 \pm 0.07^{b}$ & $13.23 \pm 0.38^{d}$ & $115.91 \pm 4.02^{\mathrm{a}}$ & $27.26 \pm 1.39^{a b}$ & $23.5 \pm 0.46^{\mathrm{ab}}$ \\
\hline \multirow{2}{*}{ T2 (protexin) } & 1 & $3.82 \pm 0.16^{\mathrm{ab}}$ & $1.63 \pm 0.06^{\mathrm{a}}$ & $17.03 \pm 0.42^{\mathrm{ab}}$ & $104.42 \pm 1.78^{\mathrm{b}}$ & $23.54 \pm 1.95^{b}$ & $22.5 \pm 1.49^{a b}$ \\
\hline & 2 & $4.20 \pm 0.17^{a}$ & $1.6 \pm 0.07^{a}$ & $17.13 \pm 0.54^{\mathrm{a}}$ & $110.7 \pm 4.62^{\mathrm{ab}}$ & $27.19 \pm 1.83^{\mathrm{ab}}$ & $25.05 \pm 0.1^{\mathrm{ab}}$ \\
\hline \multirow{2}{*}{ T3 (Biogen-S) } & 1 & $3.58 \pm 0.11^{b}$ & $1.46 \pm 0.08^{a}$ & $16.35 \pm 0.72^{\mathrm{abc}}$ & $108.47 \pm 1.88^{\mathrm{ab}}$ & $23.82 \pm 0.25^{b}$ & $21.98 \pm 0.61^{b}$ \\
\hline & 2 & $3.99 \pm 0.19^{a b}$ & $1.64 \pm 0.06^{\mathrm{a}}$ & $16.4 \pm 0.38^{a b c}$ & $104.71 \pm 2.8^{b}$ & $24.44 \pm 1.23^{\mathrm{ab}}$ & $23.87 \pm 1.28^{\mathrm{ab}}$ \\
\hline \multirow{2}{*}{ T4 (Diamond-V) } & 1 & $3.60 \pm 0.06^{b}$ & $1.46 \pm 0.06^{\mathrm{a}}$ & $15.22 \pm 0.4^{c}$ & $101.34 \pm 5.7^{b}$ & $23.96 \pm 1.05^{b}$ & $23.67 \pm 0.28^{\mathrm{ab}}$ \\
\hline & 2 & $3.98 \pm 0.22^{\mathrm{ab}}$ & $1.57 \pm 0.05^{\mathrm{a}}$ & $15.67 \pm 0.23^{b c}$ & $100.15 \pm 2.63^{b}$ & $25.39 \pm 0.7^{\mathrm{ab}}$ & $25.42 \pm 1.33^{a}$ \\
\hline Two way ANOVA & \multicolumn{7}{|c|}{$P$ Value } \\
\hline Prob. & & 0.0001 & 0.0001 & 0.0001 & 0.002 & 0.047 & 0.461 \\
\hline Month & & 0.008 & 0.081 & 0.377 & 0.941 & 0.211 & 0.059 \\
\hline Prob. $\times$ Month & & 0.582 & 0.438 & 0.926 & 0.485 & 0.337 & 0.449 \\
\hline
\end{tabular}

The values were given as means ( \pm S.E.) of three replicates. Means values with different superscript letters within the same columns are differ significantly at $(P \leq 0.05)$. Means with same letters within column non-differ significantly, $P \leq 0.05$ (a- $c)$.

Table 5. Effect of probiotics on leukogram of Nile tilapia fed different probiotics for the first and the second month.

\begin{tabular}{|c|c|c|c|c|c|}
\hline Groups & Month & WBCs $(\times 103 / \mu \mathrm{l})$ & Neutrophil (\%) & Lymphocyte (\%) & Monocyte (\%) \\
\hline \multirow[t]{2}{*}{ T1 (control) } & 1 & $5.12 \pm 0.45^{c}$ & $32.72 \pm 0.91^{a}$ & $42.45 \pm 1.65^{d}$ & $4.9 \pm 0.38^{c}$ \\
\hline & 2 & $5.35 \pm 0.43^{c}$ & $31.33 \pm 1.51^{\mathrm{a}}$ & $42.65 \pm 1.18^{d}$ & $5.8 \pm 1.02^{b c}$ \\
\hline \multirow[t]{2}{*}{ T2 (protexin) } & 1 & $7.70 \pm 0.29^{a b}$ & $19.46 \pm 0.51^{b c}$ & $62.37 \pm 1.45^{\mathrm{bc}}$ & $7.8 \pm 0.94^{\mathrm{ab}}$ \\
\hline & 2 & $8.7 \pm 0.56^{a}$ & $18.07 \pm 0.59^{c}$ & $70.55 \pm 1.82^{a}$ & $9.1 \pm 0.29^{a}$ \\
\hline \multirow[t]{2}{*}{ T3 (Biogen-S) } & 1 & $6.65 \pm 0.55^{\mathrm{b}}$ & $21.03 \pm 1.15^{\mathrm{b}}$ & $58.03 \pm 1.43^{c}$ & $7.36 \pm 0.64^{a b}$ \\
\hline & 2 & $8.44 \pm 0.38^{a}$ & $17.75 \pm 1.07^{c}$ & $67.08 \pm 2.43^{\mathrm{ab}}$ & $6.8 \pm 0.33^{a b c}$ \\
\hline \multirow{2}{*}{ T4 (Diamond-V) } & 1 & $6.75 \pm 0.26^{b}$ & $20.29 \pm 0.28^{b c}$ & $59.5 \pm 1.02^{c}$ & $7.4 \pm 0.49^{\mathrm{ab}}$ \\
\hline & 2 & $7.93 \pm 0.42^{\mathrm{ab}}$ & $18.85 \pm 0.32^{b c}$ & $67.87 \pm 1.94^{a}$ & $7.1 \pm 86^{\mathrm{ab}}$ \\
\hline Two way ANOVA & \multicolumn{5}{|c|}{ P Value } \\
\hline Prob. & & 0.0001 & 0.0001 & 0.0001 & 0.003 \\
\hline Month & & 0.003 & 0.009 & 0.0001 & 0.435 \\
\hline Prob. $\times$ Month & & 0.373 & 0.655 & 0.055 & 0.465 \\
\hline
\end{tabular}

The values were given as means ( \pm S.E.) of three replicates. Means values with different superscript letters within the same columns are differ significantly at $(\mathrm{P} \leq 0.05)$. Means with same letters within column non-differ significantly, $\mathrm{P} \leq 0.05(\mathrm{a}-\mathrm{c})$.

proinflamatory cytokine genes TNF- $\alpha$ and IL1- $\beta$ in the head kidneys of the Nile tilapia were evaluated at the end of the feeding trials. The transcript level of all these genes relative to the house- keeping gene $\beta$-actin was indicated in Figure 1. Dietary probiotics (protexin, biogen and diamond) supplementation caused significant upregulation in IL-1 and TNF a mRNA levels in the pattern of T2 > T3 > T4 compared with the control $\beta$-actin levels.

\section{Challenge test}

From Table 8, It was noticed that, the highest mortality percentage was in $\mathrm{T} 1(70 \%)$ while the lowest mortality observed in T2 $(30 \%)$. Relative level of protection (RLP) was higher in T2 (47.6\%).

\section{Antibody titer}

Results of Table 9 showed that the highest level of the antibody titre to $A$. hydrophila infection was obtained with T2 $\left(9 \log _{10}\right)$. Also high values were obtained in T3 and T4 as compared to $\mathrm{T} 1$.

\section{DISCUSSION}

Nile tilapia, Oreochromis niloticus is one of the most 
Table 6. Effect of probiotics on some liver function tests of Nile tilapia fed different probiotics for the first and the second month.

\begin{tabular}{|c|c|c|c|c|c|c|c|}
\hline Groups & Month & $\operatorname{ALT}(\mathbf{u} / \mathrm{l})$ & AST (u/l) & $\begin{array}{c}\text { Total protein } \\
\text { (g/dl) }\end{array}$ & $\begin{array}{l}\text { Albumin } \\
\text { (g/dl) }\end{array}$ & $\begin{array}{c}\text { Globulin } \\
\text { (g/dl) }\end{array}$ & A/G Ratio \\
\hline \multirow[b]{2}{*}{ T1 (control) } & 1 & $32.73 \pm 0.93^{a}$ & $57.28 \pm 0.51^{a}$ & $2.61 \pm 0.14^{c}$ & $0.92 \pm 0.029^{b c}$ & $1.68 \pm 0.11^{b}$ & $0.55 \pm 0.03^{a}$ \\
\hline & 2 & $29.91 \pm 0.33^{a}$ & $55.46 \pm 1.07^{a}$ & $2.79 \pm 0.10^{\mathrm{bc}}$ & $1.05 \pm 0.026^{\mathrm{ab}}$ & $1.74 \pm 0.11^{b}$ & $0.60 \pm 0.05^{a}$ \\
\hline \multirow{2}{*}{ T2 (protexin) } & 1 & $23.00 \pm 0.96^{b}$ & $40.44 \pm 0.32^{c}$ & $3.26 \pm 0.04^{\mathrm{ab}}$ & $0.92 \pm 0.023^{c}$ & $2.34 \pm 0.07^{a}$ & $0.39 \pm 0.02^{b}$ \\
\hline & 2 & $24.61 \pm 0.53^{b}$ & $44.18 \pm 1.40^{\mathrm{bc}}$ & $3.63 \pm 0.14^{\mathrm{a}}$ & $1.08 \pm 0.046^{\mathrm{a}}$ & $2.54 \pm 0.13^{a}$ & $0.43 \pm 0.03^{b}$ \\
\hline \multirow{2}{*}{ T3 (Biogen-S) } & 1 & $26.00 \pm 2.50^{\mathrm{b}}$ & $46.00 \pm 2.02^{b}$ & $3.22 \pm 0.14^{\mathrm{ab}}$ & $0.93 \pm 0.019 \mathrm{bc}$ & $2.32 \pm 0.17^{a}$ & $0.38 \pm 0.04^{b}$ \\
\hline & 2 & $25.01 \pm 0.68^{b}$ & $46.30 \pm 3.06^{b}$ & $3.48 \pm 0.17^{\mathrm{a}}$ & $1.13 \pm 0.079^{a}$ & $2.38 \pm 0.06^{a}$ & $0.46 \pm 0.03^{b}$ \\
\hline \multirow{2}{*}{ T4 (Diamond-V) } & 1 & $23.84 \pm 1.35^{\mathrm{b}}$ & $48.14 \pm 1.68^{b}$ & $3.16 \pm 0.13^{\mathrm{ab}}$ & $0.83 \pm 0.021^{c}$ & $2.26 \pm 0.14^{a}$ & $0.44 \pm 0.03^{b}$ \\
\hline & 2 & $24.73 \pm 1.17^{b}$ & $47.39 \pm 0.68^{b}$ & $3.56 \pm 0.33^{\mathrm{a}}$ & $1.05 \pm 0.037^{\mathrm{ab}}$ & $2.56 \pm 0.28^{a}$ & $0.38 \pm 0.01^{b}$ \\
\hline Two way ANOVA & \multicolumn{7}{|c|}{ P Value } \\
\hline Prob. & & 0.0001 & 0.0001 & 0.001 & 0.171 & 0.0001 & 0.0001 \\
\hline Month & & 0.712 & 0.747 & 0.023 & 0.0001 & 0.16 & 0.25 \\
\hline Prob. $\times$ Month & & 0.305 & 0.36 & 0.905 & 0.699 & 0.826 & 0.2 \\
\hline
\end{tabular}

The values were given as means $( \pm$ S.E.) of three replicates. Means with different letters within column differ significantly, $P \leq 0.05$, Means with same letters within column non-differ significantly, $\mathrm{P} \leq 0.05(\mathrm{a}-\mathrm{c})$.

Table 7. Effect of probiotics on some immunological parameters in O. niloticus after the first and second month of experiment.

\begin{tabular}{lccc}
\hline Groups & Month & NBT $(\mathrm{mg} / \mathrm{ml})$ & Lysozyme $(\mu \mathrm{g} / \mathrm{ml})$ \\
\hline T1 (control) & 1 & $1.02 \pm 0.04^{\mathrm{d}}$ & $0.83 \pm 0.09^{\mathrm{d}}$ \\
& 2 & $1.00 \pm 0.06^{\mathrm{d}}$ & $1.13 \pm 0.10^{\mathrm{cd}}$ \\
T2 (protexin) & 1 & $2.11 \pm 0.13^{\mathrm{a}}$ & $1.55 \pm 0.09^{\mathrm{ab}}$ \\
& 2 & $1.97 \pm 0.07^{\mathrm{a}}$ & $1.75 \pm 0.17^{\mathrm{a}}$ \\
T3 (Biogen-S) & 1 & $1.66 \pm 0.05^{\mathrm{c}}$ & $1.41 \pm 0.08^{\mathrm{bc}}$ \\
& 2 & $1.73 \pm 0.04^{\mathrm{bc}}$ & $1.87 \pm 0.12^{\mathrm{a}}$ \\
T4 (Diamond-V) & 1 & $1.6 \pm 0.09^{\mathrm{c}}$ & $1.29 \pm 0.06^{\mathrm{bc}}$ \\
& 2 & $1.90 \pm 0.03^{\mathrm{ab}}$ & $1.74 \pm 0.07^{\mathrm{a}}$ \\
Two way ANOVA & & \multicolumn{2}{c}{$\mathrm{P}$ Value } \\
Probiotic & & 0.0001 & 0.0001 \\
Month & & 0.272 & 0.0002 \\
Prob $\times$ Month & & 0.037 & 0.547 \\
\hline
\end{tabular}

The values were given as means ( \pm S.E.) of three replicates. Means with different letters within column differ significantly, $\mathrm{P} \leq 0.05$, Means with same letters within column non-differ significantly, $\mathrm{P} \leq 0.05$ (a- C).

important species, and its growth performance and diseases resistance are critical keys for its culture expansion (Abdel-Tawwab et al., 2008). Probiotic supplementation enhanced growth performance in the first and second month of the experiment over control diet. The noticed increase in the body weight may be due to high food utilization and the increase in digestibility of different diet components. A similar enhancement of growth performance was reported in Nile tilapia supplemented with Enteroccus faecium (Wang et al., 2008a), S. cerevisiae (Abdel-Tawwab et al., 2008; Goda et al., 2012) and with bacterial cocktail of (Lactobacillus acidophilus, Streptococcus thermophilus, and Bifidobacterium bifidum) (Ayyat et al., 2014). On the contrary, Iwashita et al. (2015) mentioned that administration of a combination of probiotics of $B$. subtilis, S. cerevisiae and A. oryzae had no effect on the growth rates of Nile tilapia.

The hematological and biochemical parameters usually give a good picture for fish health and well-being monitoring (Eissa and Abou-El Gheit 2014). In the present 


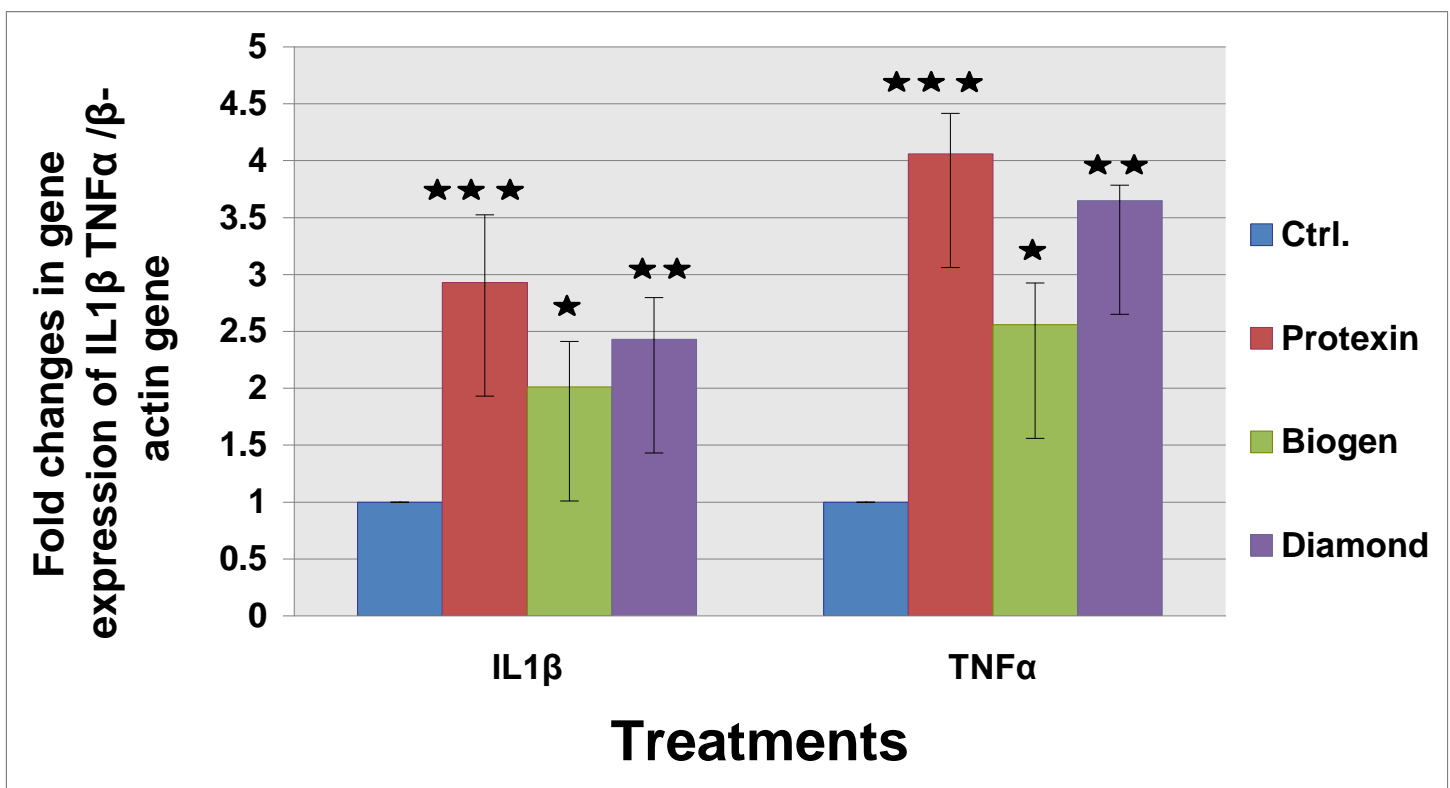

Figure 1. Graphical presentation of real time quantitative PCR analysis of the expression of proinflamatory cytokine TNFa and IL1 $\beta$ genes of Nile tilapia fed different probiotics for two months. *showed significant difference between treatments and control.

Table 8. Mortality rates and RLP among the experimentally infected Nile tilapia fed different probiotics for 14 days.

\begin{tabular}{llcccc}
\hline Groups & Treatment & Number of fish & Number of dead fish & Mortality \% & RLP\% \\
\hline T1 (control) & A. hydrophila & 30 & 21 & 70 & 0.0 \\
T2 & A. hydrophila + PROTEXIN & 30 & 9 & 30 & 47.6 \\
T3 & A. hydrophila + BIOGEN & 30 & 11 & 36.67 & 33.3 \\
T4 & A. hydrophila + DIAMOND & 30 & 16 & 40 & 23.8 \\
\hline
\end{tabular}

Table 9. Effect of prebiotics supplemented diet on the antibody titre level due to A. hydrophila infection.

\begin{tabular}{lcccc}
\hline \multirow{2}{*}{ Antigen } & \multicolumn{5}{c}{ Antibody titre (log10) } \\
\cline { 2 - 5 } & T1 & T2 & T3 & T4 \\
\hline A. hydrophila & 4 & 9 & 7 & 6 \\
\hline
\end{tabular}

work, there was significant improvement in fish fed probiotic-enriched diets in (T2, T3 and T4) compared to the control (T1). This indicates that all types of probiotics have positive impact on erythrogram. Consequently, there was a significant increase in blood indices like Mean Corpuscular Volume (MCV) and Mean Corpuscular Hemoglobin $(\mathrm{MCH})$ but not for $\mathrm{MCHC}(\mathrm{P}>0.05)$. This confirm the findings of Abd Elaziz et al. (2007) who observed significant increases in RBCs count, WBCS count, $\mathrm{Hb}$ concentration and $\mathrm{PCV} \%$ in Nile tilapia received two types of probiotics (Bacillus subtilis and saccharomyces cerevisiae). The enhancement of the erythrogram parameters may be attributed to the hepatostimulatory and hepato-protective effects of probiotics (Sarma et al., 2003).

Leukocytosis with neutrophilia and lymphocytosis were observed in treated groups when comparing with the control fish. In the same line, Tantawy et al. (2009) and Mehrim (2011) also noticed increases in total and differential leukocytic counts (lymphocytes, heterophils and monocytes) in probiotic-supplemented fish.

The innate immunity is correlated with serum protein, albumin and globulin levels (Wiegertjes et al. 1996). Fish administrated probiotics revealed hyperproteinemia and 
hyperglobulinemia. The obtained results validate those of Kumar et al. (2006) and Nayak et al. (2007) who found higher total serum protein and globulins in Nile tilapia fed probiotic in diet while albumin was not affected by probiotic supplementation. As the source of antibody in blood serum is globulin, the total serum globulin level probably reflects the level of specific immunoglobulin (antibody). Otherwise, Ayyat et al. (2014) reported that, highest serum albumin level was obtained in the group of fish fed the threebacteria cocktail (Lactobacillus acidophilus, Streptococcus thermophilus, and Bifidobacterium bifidum).

A significant decrease $(p<0.05)$ in the serum levels of Alanine aminotransferase (ALT), Aspartate aminotransferase (AST) and glucose along the experimental periods were noticed in probioticssupplemented groups. Nile tilapia also revealed the same behavior of transaminases decrease under the effect of dead Saccharomyces cerevisiae yeast (Abdel-Tawwab et al., 2008) and both of live Bacillus subtilis and S. cerevisiae (Marzouk et al., 2008), B. licheniformis (Soltan and ElLaithy, 2008) and E. faecium and B. coagulans (Elmoghazy Mohamed et al., 2015). Talib (2004) indicated that probiotics has no hepatotoxic or nephrotoxic effects in Oreochromis niloticus and Mugil cephalus. Silva et al. (2015) noticed that $B$. amyloliquefaciens seems to have positively influenced the glucose levels of fish in cagereared Nile tilapia.

In the present study, fish fed one of the tested probiotics (Protexin, Biogen-S and Diamond V) showed higher immunity as indicated by respiratory burst and lysozyme activities than those fed the control diet. Similar results were reported when Nile tilapia fed baker yeast (AbdelTawwab et al., 2008), B. subtilis and L. acidophilus or each one alone (Aly et al., 2008), E. faecium ZJ4 (Wang et al., 2008a), Spirulina (Abdel-Tawwab and Ahmad, 2009) and B. amyloliquefaciens (Selim and Reda, 2015).

Lysozyme is an indispensable bactericidal cationic enzyme that hydrolyzes the peptidoglycan layers of bacterial cell walls by splitting glycosidic bonds between $\mathrm{N}$-acetylmuramic acid and $\mathrm{N}$ - acetylglucosamine and is increased in the sera of fish during infection with various variable microorganisms (Magnadottir, 2006). High nonspecific immunity was developed in Nile tilapia that was fed diets supplemented with probiotics (T2, T3 and T4) which resulted in an increase in the serum lysozyme. Dietary supplementation with different probiotic strains enhances lysozyme activity in tilapia (Ridha and Azad, 2012), rainbow trout, Oreochromis mykiss (Panigrahi et al., 2005; Kim and Austin, 2006; Ramos et al., 2013) and seabream (Picchietti et al., 2007). In contrast, dietary or water supplemented with Bacillus spp. fails to increase serum lysozyme levels in tilapia and rainbow trout (Zhou et al., 2010).

Cytokines are simple polypeptide or glycoprotein mediators that are produced by immune cells and act as signaling molecules for the immune system and contribute to cell growth and differentiation and defense mechanisms of the host (Ellis, 2001; Peddie et al., 2002). Proinflammatory cytokines, including interleukin-1 (IL-1 $\beta$ ) and tumor necrosis factor-alpha (TNF- $\alpha$ ), are biomarker immune- regulators and activate lymphocytes, macrophages and natural killer cells, which results in subsequent enhancements of phagocytosis, respiratory burst activity and nitric oxide production (Mulero and Meseguer, 1998). In the present study, probiotics administration modulated the production of IL-1 $1 \beta$ and TNF$\alpha$ in tilapia following 2 months of feeding trials. He et al. (2013) reported that the expression of the immune response genes IL-1 and TNF $\alpha$ significantly increased in tilapia fed $B$. subtilis after 56 days of feeding. Similar modulations have been reported in rainbow trout fed Bacillus subtilis, Lactococcus rhamnosus or Lactococcus garvieae (Awad et al., 2011, Nayak, 2010, Pérez-Sánchez et al., 2011). In contrary, cytokines IL-1 and TNF- $\alpha$ have been reported to be down-regulated by Lactococcus delbrueckii supplementation through live carriers in Dicentrarchus labrax (Picchietti et al., (2009). Probiotic bacteria colonize in the gut and are involved with the gutassociated lymphoid tissue to stimulate systemic signals that end with cytokine production (Zhigang, 2011).

Fish prophylacted by probiotics then challenged with $A$. hydrophila showed a statistical improvement in survival percent between treated groups than control one. These findings are substantiated by Abdel-Tawwab et al. (2008) who found that Nile tilapia fed baker yeast and challenged by $A$. hydrophila showed lower mortality than those fed the control diet. Villamil et al. (2014) found that survival percent was $80.1 \%$ in L. acidophilus fed groups compared with $46.6 \%$ in Nile tilapia fed the control diet and infected with $A$. hydrophila.

The highest level of the antibody titer after $\mathrm{i} / \mathrm{p}$ with $A$. hydrophila was obtained with T2 and the lowest value was obtained with the control fish. Statistical increase in total serum immunoglobulin levels was reported in rainbow trout, Oncorhynchus mykiss (Panigrahi et al., 2004) and the Indian major carp, Labeo rohita, fed diet containing $B$. subtilis (Nayak et al., 2007).

\section{Conclusion}

Improvement in growth performance was achieved when Nile tilapia fed diets containing Protexin, Biogen-S or Diamond V) for 2 months. Also, fish health and innate immunity was significantly improved by the dietary administration of any of the probiotics. The interleukin-1 (IL-1) and tumor necrosis factor a (TNFa) mRNA levels in the anterior kidney tissues increased significantly in the supplemented groups. These increases in the examined immune parameters following the administration of the probiotic were correlated with an improvement in the fish survivability of inoculations with $A$. hydrophila. 


\section{REFERENCES}

Abd Elaziz, M., Ali, M., Safaa, Y., Raafat, A., \& Safinaz, R., (2007). Study on the effects of some probiotics on the performance, clinicopathological and histopathological changes of Oreochromis niloticus. Vet. Med. J., Giza, 55(3), 879-897.

Abdel-Tawwab, M., \& Ahmad, M. H. (2009). Live Spirulina (Arthrospira platensis) as a growth and immunity promoter for Nile tilapia, Oreochromis niloticus (L.), challenged with pathogenic Aeromonas hydrophila, Aquac. Res., (40), 10371046.

Abdel-Tawwab, M., Abdel-Rahman, A. M., \& Ismael, N. E. (2008). Evaluation of commercial live bakers' yeast, Saccharomyces cerevisiae as a growth and immunity promoter for Fry Nile tilapia, Oreochromis niloticus (L.) challenged insitu with Aeromonas hydrophila. Aquaculture, 280, 185-189.

Aly, S. M., Ahmed, Y. A., Mohamed, M. F., Ahlam, A., \& Ghareeb, A. (2008). Studies on Bacillus subtilis and lactobacillus acidophilus as potential probiotics on the immune response and resistance of Tilapia nilotica (Oreochromis niloticus) to challenge infections. Fish and Shellfish Immunology, 25,128136.

AOAC (2000). Official Methods of Analysis, 15th ed., Association of Official Analysis of Chemist, Washington.

Awad, E., Mitchell, W. J., \& Austin, B. (2011). Effect of dietary supplements on cytokine gene expression in rainbow trout, Oncorhynchus mykiss (Walbaum). Journal of Fish Diseases, 34, 629-634.

Ayyat, M. S., Labib, H. M., \& Mahmoud, H. K. (2014). A probiotic cocktail as a growth promoter in Nile Tilapia (Oreochromis niloticus). J. Appl. Aquac., 26 (3), 208-215.

Balcázar, J. I., Blas, I., Ruiz-Zarzuela, I., Cunningham, D., Vendrell, D., \& Muzquiz, J. L. (2006). The role of probiotics in aquaculture. Vet. Microbiol., (114),173-186.

Dacie, S. V., \& Lewis, S. M. (1991). "Practical Hematology". 7th Ed., Churchill Livingstone, London. p. 556.

De Silva, S. S., \& Anderson, T. A. (1995). Fish nutrition in aquaculture, 1st edn. Chapman and Hall, London. p. 319.

Doumas, B. T., \& Biggs, H. G. (1972). Determination of serum globulin, in. Standard Methods of Clinical Chemistry Vol. 7 Edited by Cooper, Academic Press, New York). p. 175.

Doumas, B. T., Bayso, D. D., Carter, R. J., Peter, T., \& Schaffer, R. (1981). Determination of serum albumin. Clin. Chem., 27, 1642.

Eissa, N., \& Abou-EIGheit, E. (2014). Dietary supplementation impacts of potential non- pathogenic isolates on growth performance, hematological parameters and disease resistance in Nile tilapia (Oreochromis niloticus). J. Veterinary Adv., 4(10), 712-719.

Ellis, A. (2001). Innate host defense mechanisms of fish against viruses and bacteria. Dev. Comp. Immunol., 25, 827-839.

El-moghazy Mohamed, S., Mehisan Gihan, M., El-sayed Abd Elkarim, I., \& Iraqi, M. (2015). Role of probiotics in improving growth performance, immunity and controlling Aeromonas hydrophila in the Nile tilapia Oreochromis niloticus. Egypt. J. Aquat. Biol. and Fish, 19(3), 55-70.

FAO (Food and Agriculture Organization) (2016). Aquaculture Big Numbers. Fisheries and Aquaculture Technical Paper No. 601.2070-7010. Rome, Italy.

Feldman, B. F., Zinki, J. G., \& Jain, V. C. (2000). Schalm's Veterinary Hematology, 5th Edition, Lippincott Williams and
Wilkins, Canada.

Goda, A. M. A., Mabrouk, H. A. H., Wafa, M. A., \& El-Afifi, T. M. (2012). Effect of Using Baker's Yeast and Exogenous Digestive Enzymes as Growth Promoters on Growth, Feed Utilization and Hematological Indices of Nile tilapia, Oreochromis niloticus Fingerlings. Journal of Agricultural Science and Technology, B2, 15-28.

Grant, G. H., Silverman, L. M., \& Christenson, R. H. (1987). Aminoacids and proteins, in. Fundamental of Clinical Chemistry. 3th Ed., Philadelphia, WB Saunders Company.

Gullian, M., Thompson, F., \& Rodriguez, J. (2004). Selection of probiotic bacteria and study of their immunostimulatory effect in Penaeus vannamei. Aquaculture, 233, 1-14.

He, S., Zhang, Y., Xu, L., Yang, Y., Marubashi, T., Zhou, Z., \& Yao, B. (2013). Effects of dietary Bacillus subtilis C-3102 on the production, intestinal cytokine expression and autochthonous bacteria of hybrid tilapia Oreochromis niloticus $q \times$ Oreochromis aureus $\delta$. Aquaculture, 412-413.

Irianto, A., \& Austin, B. (2002). Probiotics in aquaculture (Review). J Fish Dis., 25.633-642.

Iwashita, I. B., Nakandakare, J. S., Terhune, T., \& Wood, M. J. (2015). Dietary supplementation with Bacillus subtilis, Saccharomyces cerevisiae and Aspergillus oryzae enhance immunity and disease resistance against Aeromonas hydrophila and Streptococcus iniae infection in juvenile tilapia Oreochromis niloticus. Fish and Shellfish Immunol., 43, 60-66.

Jauncey, K. \& Ross, B. (1982). A guide to Tilapia feeds and feeding. University of Stirling, institute of Aqua culture, Stirling, Scotland. p. 62.

Kautsky, N., Ronnbäck, P., Tedengren, M., \& Troell, M. (2000). Ecosystem perspectives on management of disease in shrimp pond farming. Aquaculture, 191, 145-161.

Kesarcodi-Watson, A., Kaspar, H., Lategan, M. J., \& Gibson, L. (2008). Probiotics in aquaculture. The need, principles and mechanisms of action and screening processes. Aquaculture, $274,1-14$

Kim, D. H., \& Austin, B. (2006). Innate immune responses in rainbow trout (Oncorhynchus mykiss, Walbaum) induced by probiotics. Fish and Shell fish immunology, 21, 513-524.

Kumar, R., Mukherjee, S. C., Prasad, K. P., \& Pal, A. K. (2006). Evaluation of Bacillus subtilis as a probiotic to Indian major carp Labeo rohita (Ham.). Aquac Res 37, 1215-1221.

Livak, K. J., \& Schmittgen, T. D. (2001). Analysis of Relative Gene Expression Data Using Real-Time Quantitative PCR and the 2- [Delta][Delta]CT Method. Methods, 25(4), 402 - 408.

Magnadottir, B. (2006). Innate immunity of fish (overview). Fish and Shellfish Immunology, 20,137-151.

Martins, M. L., Pilarsky, F., Onaka, E. M., Nomura, D. T., Fenerick, J., Ribeiro, K., Myiazaki, D. M. Y., Castro, M. P., Malheiros, E. B. (2004). Hematology and inflammatory response in Oreochromis niloticus subjected to single stimuli and consecutive stress of capture. Bull. Instit. Fish. 30, 71-80.

Marzouk, M. S., Moustafa, M. M., \& Nermeen, M. M. (2008). The influence of some probiotics on the growth performance and intestinal microbial flora of $O$. niloticus. 8th International Symposium on Tilapia in Aquaculture, Pp. 1059-1071.

Matsuzaki, T. \& Chin, J. (2000). Modulating immune responses with probiotic bacteria. Immunology and Cell Biology, 78, 6773.

Mehrim, A. I. (2011). Effect of dietary supplementation of Biogen (commercial probiotic) on Mono- Sex Nile tilapia (Oreochromis niloticus) under different stoking denisities. Journal of Fisheries 
and Aquatic Science, 4(6), 261-273.

Merrifield, D. L., Dimitroglou, A., Foey, A., Davies, S.J., Baker, R.T.M., Bøgwald, J., Castex, M., \& Ringø, E. (2010b). Review. The current status and future focus of probiotic and prebiotic applications for salmonids. Aquaculture, 302, 1-18.

Mulero, V., \& Meseguer, J. (1998). Functional characterisation of a macrophage- activating factor produced by leucocytes of gilthead seabream (Sparus aurata L.), Fish and Shellfish Immunology, 8, 143-156.

Nayak, S. K. (2010). Probiotics and immunity. a fish perspective. Fish and Shellfish Immunology, 29, 2-14.

Nayak, S. K., Swain, P., \& Mukherjee, S. C. (2007). Effect of dietary supplementation of probiotic and vitamin $\mathrm{C}$ on the immune response of Indian major carp, Labeo rohita (Ham.) Fish and Shellfish Immunology, 23, 892-896.

Noordiyana, M. N., Noraisyah, R., Muhammad, Z. S., \& Sharifah, N. E. (2015). Inclusion methods and storage conditions of commercial probiotics, Bacillus sp. in aqua feed. AACL Bioflux (Aquaculture, Aquarium, Conservation and Legislation International Journal of the Bioflux Society), 8(5), 779-783.

Panigrahi, A., Kiron, V., Kobayashi, T., Puangkaew, J., Satoh, S., \& Sugita, H. (2004). Immune responses in rainbow trout Oncorhynchus mykiss induced by a potential probiotic bacteria Lactobacillus rhamnosus JCM 1136. Veterinary Immunology and Immunopathology, 102(4), 379-388.

Panigrahi, A., Kirona, V., Puangkaewa, J., Kobayashib, T., Satoha, S., \& Sugitac, H. (2005). The viability of probiotic bacteria as a factor influencing the immune response in rainbow trout Oncorhynchus mykiss. Aquaculture, 243, 241254.

Peddie, S., Zou, J \& Secombes, C. J. (2002). Immunostimulation in the rainbow trout (Oncorhynchus mykiss) following intraperitoneal administration of ergosan. Vet. Immunopathol., 86,101-13.

Pérez-Sánchez, T., Balcázar, J. L., Merrifield, D. L., Carnevali, O., Gioacchini, G., de Blas, I., \& Ruiz-Zarzuela, I. (2011). Expression of immune-related genes in rainbow trout (Oncorhynchus mykiss) induced by probiotic bacteria during Lactococcus garvieae infection. Fish and shellfish immunology, 31(2), 196-201.

Picchietti, S., Fausto, A. M., Randelli, E., Carnevali, O., Taddei, A. R., \& Buonocore, F. (2009). Early treatment with Lactobacillus delbrueckii strain induces an increase in intestinal T-cells and granulocytes and modulates immunerelated genes of larval Dicentrarchus labrax (L.), Fish and Shellfish Immunology, 26, 368-376.

Picchietti, S., Mazzini, M., Taddei, A. R., Renna, R., Fausto, A. M., \& Mulero V. (2007). Effects of administration of probiotic strains on GALT of larval gilthead seabream. immunohistochemical and ultrastructural studies. Fish and Shellfish Immunology, 22, 57-67.

Ramos, M. A., Weber, B., Gonçalves, J. F., Santos, G. A., Rema, P., \& Ozorio, R. O. A. (2013). Dietary probiotic supplementation modulated gut microbiota and improved growth of juvenile rainbow trout (Oncorhynchus mykiss). Comparative Biochemistry and Physiology Part A: Molecular \& Integrative Physiology, 166(2), 302-307.

Reitman, S., \& Frankel, S. (1957). Colorimetric method for determination of serum transminases activities. Am. J. Clin. Path., 28, 56-68.

Rengpipat, S., Rukpratanporn, S., Piyatiratitivorakul, S., \& Menasaveta, P. (2000). Immunity enhancement in black tiger shrimp (Penaeus monodon) by a probiont bacterium (Bacillus S11). Aquaculture, 191, 271- 288.

Ridha, M. T., \& Azad, I. S. (2012). Preliminary evaluation of growth performance and immune response of Nile tilapia Oreochromis niloticus supplemented with two putative probiotic bacteria, Aquac. Res., 43, 843-852.

Ruangroupan, L., Kitao, T., \& Yoshida, T. (1986). Protective efficacy of Aeromonas hydrophila vaccines in Nile tilapia. Veterinary Immunology and Immunopathology, 12(1-4), 345350.

Sarma, M., Sapcota, D., Sarma, S., \& Gohain, A. K. (2003). Herbal growth promoters on hemato-biochemical constituents in broilers. Indian Vet. J., 80, 946-948.

Schäperclaus, W., Kulow, H., \& Schreckenbach, K. (1992). Fish disease. Rotterdam, the Netherlands. A.A. Balkema. Pp. 101105.

Selim, K. M., \& Reda, R. M. (2015). Improvement of immunity and disease resistance in the Nile tilapia, Oreochromis niloticus, by dietary supplementation with Bacillus amyloliquefaciens. Fish and Shellfish Immunology Journal, 44, 496-503.

Siddiqui, A. Q., Howloder, M. S., \& Adam, A. A. (1988). Effect of dietary protein levels on growth, feed conversion and protein utilization in fry of young Nile Tilapia (Oreochromis niloticus). Aquaculture, 70, 63-73.

Silva, T. A., Petrillo, T. R., Yunis-aguinaga, J., Fernandes, P., Claudiano, S., Moraes, F. R., \& Moraes, J. R. E. (2015). Effects of the probiotic Bacillus amyloliquefaciens on growth performance, hematology and intestinal morphometry in cagereared Nile tilapia. Lat. Am. J. Aquat. Res., 43(5), 963-971.

Siwicki, A. K., Studnicka, M., \& Ryka, B. (1985). Phagocytic ability of neutrophils in carp (Cyprinus carpio L.). Isr J AquacBamid, 37, 123-128.

Soltan, M. A., \& El-Laithy, S. M. M. (2008). Effect of probiotics and some spices as feed additives on the performance and behaviour of Nile tilapia, Oreochromis niloticus. Egypt. J. Aquat. Biol. Fish, 12(2), 63-80.

Stoskopf, M. K. (1993). "Fish Medicine" W. B. Saunders Company, Philadelphia, London, pp 232-239.

Talib, A. E. (2004). Effect of biogen and bio-mas on growth performance, production and some biochemical changes in Oreochromis niloticus and Mugil cephalus. In 1st Annual Conference of Faculty of Veterinary Medicine. Moshtohor, Egypt, 322-336.

Tamhane, A. C., \& Dunlop, D. D. (2000). Statistics and Data Analysis from Elementary to Intermediate. Upper Saddle River. USA.

Tantawy, H. M., Badran, A. F., \& Rowida, H. O. (2009). The viability of probiotic bacteria (Lactobacillus acidophilus) as a factor influencing immune response and liver functions of common carp (Cyprinus carpio). Suez Canal Vet. Med. J., 14(2), 145-152.

Trinder, P. (1969). Determination of glucose concentration in the blood. Ann. Clin. Biochem., 6, 24.

Verschuere, L., Rombaut, G., Sorgeloos, P., \& Verstraete, W. (2000). Probiotics bacteria as biological control agents in aquaculture. Microbiol. Mol. Biol. Rev., 64, 655-671.

Villamil, L., Reyes, C., \& Martínez-Silva, M. A. (2014). In vivo and in vitro assessment of Lactobacillus acidophilus as probiotic for tilapia (Oreochromis niloticus, Perciformes. Cichlidae) culture improvement. Aquac. Res. 45, 1116-1125.

Vine, N. G., Leukes, W. D., Kaiser, H., Daya, S., Baxter, J., \& 
Hecht (2004). Competition for attachment of aquaculture candidate probiotic and pathogenic bacteria on fish intestinal mucus. J. Fish Dis., 27, 319-326.

Wang, Y. B., Li, J. R., \& Lin, J. (2008b). Probiotics in aquaculture challenges and outlook. Aquaculture, 281, $1-4$.

Wang, Y. B., Tian, Z. Q., Yao, J. T. \& Li, W. F. (2008a). Effect of probiotics, Enteroccus faecium, on tilapia (Oreochromis niloticus) growth performance and immune response, Aquaculture, 277, 203 -207.

Welker, T., \& Lim, C. (2011). Use of probiotics in diets of Tilapia. J. Aquac. Res. Dev., 1(1), 1-8.

Wiegertjes, G. F., Stet, J. M., Parmentier, H. K., \& Muiswinkel, W. B. (1996). Immunogenetics of disease resistance in fish. a comparative approach. Dev. Comp. Immunol., 20,365-381.
Wilfinger, W. W., Mackey, K., \& Chomczynski, P. (1997). Effect of $\mathrm{pH}$ and ionic strength on the spectrophotometric assessment of nucleic acid purity. Biotechniques, 22, 474-481.

Zhigang, Z. (2011). Evaluation of probiotic strain Bacillus subtilis C-3102 as a feed supplement for koi carp (Cyprinus carpio), J. Aquac. Res. Dev., 1(1), 1-8.

Zhou, X., Tain, Z., Wang, Y., \& Li, W. (2010). Effect of treatment with probiotics as water additives on tilapia (Oreochromis niloticus) growth performance and immune response. Fish Physiol. Biochem., 36, 501-509. 